\title{
Spanish Companies' Conversion Into Cooperatives As A Collective Resistance Response To Unemployment
}

\author{
Susana B. Díaz Ruiz, University of Castilla La Mancha, Spain
}

\begin{abstract}
The samples of depletion in the current economical and productive model observed by various authors from different disciplines provide the framework of business recovery processes and companies' conversion into cooperatives by their workers. These processes can be observed in countries like Argentina, the USA, Greece and Spain.
\end{abstract}

The main reason for this response lies in the organization of collective resistance strategies to prevent unemployment. The strategies represent an implicit criticism of the economical and productive model based on increased unemployment, job insecurity and instability.

Based on the qualitative results and a set of surveys obtained in previous research conducted in Argentina (Díaz Ruiz, 2014) and using discursive material recently collected in a private company in Cuenca (Spain), this paper will study the common elements of both scenarios. The result is the depiction of the conversion processes through the subjective vision of the main protagonists.

Keywords: Companies Recovered By Their Workers; Cooperative Restructuring; Self-Management; Qualitative Research

\section{INTRODUCTION}

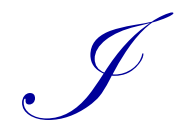

n 2004 in Argentina, there were a total of 161 companies recovered by their workers (CRWs), companies which were returned to working order by their employees after having been subject, in the majority of cases, to abandonment or illicit attempts to remove company goods by their employers (Magnani, 2003; Rebón, 2004, Ruggeri, Martínez \& Trinchero, 2005). In these circumstances, the workers adopted a system of self-management, in the form of cooperative organizations, in an attempt to prevent the loss of their work ${ }^{1}$.

In 2009, mired in the framework of the current economic crisis, 40 companies were registered in Spain as companies converted into cooperatives (CCCs) according to data provided by the Spanish Confederation of Workers' Cooperatives (Confederación de Cooperativas Españolas de Trabajo Asociado - COCETA). These are companies where, when faced with closure or cuts to the workforce, the workers, on occasion in a manner agreed with their employers, assume management of the company under cooperative organizational structures, thereby attempting to prevent the closure. According to collected data, today there are 75 such companies and, although it is difficult to produce exact figures regarding converted companies ${ }^{2}$, in 2013 it was noted that there was a rise in company recoveries as a collective strategy to self-generate employment (COCETA). This is a significant figure when compared with the total number of 150 CCCs throughout all of Europe ${ }^{3}$.

\footnotetext{
${ }^{1}$ The regions where this has taken place are various - Europe, the USA and Latin America. See, for example, the work of Andrés Ruggeri (Ruggeri, 2009).

${ }^{2}$ As the president of COCETA Paloma Arroyo explains, this difficulty lies in the fact that CCCs appear as new companies once registered as cooperatives and their prior history is not recorded (Vilnitzky, 2014).

${ }^{3}$ See the report by CECOP - CICOPA "Business Transfers to Employees under the Form of a Cooperative in Europe Opportunities and Challenges" http://www.cecop.coop/IMG/pdf/bussiness_transfers_to_employees_under_the_form_of_a_cooperative_in_europe_cecop-2.pdf.
} 
Both experiences have their own distinct circumstances and one of the principal differences is related to the level of conflict which the recovery processes in Argentina reached in the situation that the workers found themselves in. Faced with breaches of contract by their employers and with fraudulent and illicit attempts to drain corporate funds which occurred in the majority of cases (Ruggeri, 2009), 62\% of the CRWs in Argentina featured the workers using forceful measures, including takeovers, camps and demonstrations (Programa Facultad Abierta [PFA], 2010). For the workers, complying with the bankruptcy process, as recognised in the Law of Bankruptcies and Insolvency, meant complying with their loss of employment and the end of any possibility of receiving overdue salaries since under the law, payments to banks are prioritised and workers are usually left out.

However, as defensive responses when confronted with unemployment, there are elements in common. Among these, notable elements are, firstly, the high level of heterogeneity of the cases, and secondly the importance of the national crisis - not so much as a determining factor, but rather as an influence on the proliferation of cases. On the one hand, the low numerical representation of workers who undertake recovery processes and conversions to cooperatives provides evidence of the lack of the crisis's determining character as an explanatory factor for the emergence of this response.

In the case of Argentina, the majority of recoveries began between 2001 and 2004, years marked by the crisis affecting the country (PFA, 2010). However, the existence of 63 new CRW cases between 2010 and 2013 has led to a balancing out in the percentage of recoveries that took place before the crisis compared to after. This demonstrates the continuity of the recovery process beyond the crisis itself (PFA, 2014). Data collected in Spain only enable the identification of a rise in the number of conversions which coincides with the worsening of the country's social situation. According to COCETA's monitoring of CCCs, in 2013 - a year notable in Spain for the worsening of the crisis in the rise of poverty and social exclusion, a clear rise in the number of cases was observed ${ }^{4}$.

These elements mean that the recovery and conversion of companies can be understood as collective selfmanaged undertakings which emerge as defensive responses. The workers are attempting to prevent their loss of work in a situation of necessity and social urgency, marked by society-wide uncertainty and precarious labour conditions which, according to various writers, are consequences of the direction of the current paradigm of flexible production for short-term profit (Sennett, 2000; Alonso, 2000; Carnoy, 2001; Prieto, 2002; Castillo, 2003; Castells, 2005).

The aim of this paper is to identify common elements in the subjectivity of workers in the CRWs of Argentina and the CCCs in Spain, under the hypothesis that, in both cases, the workers who initiate the process of self-management embody and are protagonists in a collective defensive response to the threat of unemployment. Based on results obtained in research carried out in a CRW in Argentina relating to the view of workers towards their own recovery response (Díaz, 2014), the author has conducted recent in-depth interviews with workers at a company converted into a cooperative in Cuenca (Spain), with the aim of identifying these common elements in the workers' subjectivity and in the reasons they had for starting out on the process of self-management. The results enable the establishment of the shared meanings between the workers of both companies as actors who were protagonists in the processes.

\section{DEVELOPMENT}

The following is an analysis of common elements which are identified in the subjectivity of the workers of the CRW in Argentina and the Spanish CCC and which provide an understanding of the causes behind their collective decisions to undertake both processes of recovery and conversion as defensive strategies in the face of unemployment.

\footnotetext{
${ }^{4}$ According to statements made by Paloma Arroyo, president of COCETA, this rise was some 50\%. Accessed at Cadena Ser on 2nd April, 2014 at http://www.cadenaser.com/economia/articulo/empresas-convertidas-cooperativas-salvan-700-puestos-trabajo2013/csrcsrpor/20140421csrcsreco_1/Tes.
} 


\section{Perception Of The Situation In Which They Found Themselves}

At the time of the 2001 economic crisis in Argentina, the general situation in the country was notable for successive closures of companies, which showed the difficulties of finding alternative employment. For more than half of the population, unemployment had acquired a permanent character, which meant a situation destined for social exclusion (Perelman, 2002).

Argentine workers perceived the 2001 crisis not as a one-off scenario, but rather as the worst possible endproduct that could be expected in the face of a continual deterioration of labour conditions and employment. This led to an unsustainable situation, notable for the lack of options for an increasingly greater number of workers and for feelings of a lack of institutional protection.

They locate the change in the 1990s with the government of Carlos Menem, who put in place policies of flexibility, deregulation and privatization which had, as a consequence, the closure of thousands of companies and the consequent loss of work for the employees. The crisis aggravated the social ill-feeling in the Argentine population and the workers who found themselves faced with the closure of their companies became protagonists in a situation of the utmost seriousness. Among the different reasons they had for initiating recovery, it is worth mentioning breaches of contract in terms of the lack of payment of salaries and extra hours; in numerous cases the company owner abandoned the company and, in the majority of cases, the breakdown in company management was capped by attempts to fraudulently remove machinery and materials for their later sale (Fajn, 2003; Rebón, 2004; Ruggeri \& Trinchero, 2005; Ruggeri, 2009).

The situation they perceived was dramatic and lacking in options. For this reason, although with no guarantee of success, they began the process of recovery as an alternative to the only options they could count on insufficient unemployment benefits or trying to survive in the black market (Díaz, 2014).

In a climate of protest and social mobilization with nearly $19 \%$ of the population unemployed and more than half (54\%) afflicted by poverty (Instituto Nacional Estadística y Censos Argentina [INDEC], 2002), a state of emergency was declared on the 19th and 20th of December, 2001, and, on the 21st of December, president De la Rúa resigned. As such, the crisis had a political, as well as an economic, dimension. Politicians and business owners explicitly lost their legitimacy and this became the background to a large part of Argentine society's understanding of the actions undertaken by the workers 5 .

"We had nothing to hold on to; it was a terrible situation because after so many years working, we saw each other in the streets collecting cardboard boxes, and the whole country was the same; there was no work." (CRW worker)

In Spain, in the face of the progressive worsening of the economic crisis, cooperatives are increasingly being recognised as the organizational models most resistant to closures and the destruction of employment. In particular, converted cooperatives are presented by experts and various media outlets as alternatives, not only to the crisis but to the current model of flexible accumulation based on unlimited growth and consumption and reduced to commercialistic principles. In this sense, cooperatives, especially companies converted into cooperatives, appear within the environment of different theoretical responses shared by those who criticise the current management policy of globalization as unjust and unsustainable.

Formulas for a social economy (Razeto, 2006; Coraggio, 2004) and for the common good (Felber, 2012) are some examples which share the revaluation of what is common and of the values of equality, horizontality, solidarity and environmental sustainability in the creation of an economy in the service of the well-being of people, and which show the development of alternatives to the current commercial paradigm.

\footnotetext{
${ }^{5}$ As Julián Rebón explains, the crisis - political as well as economic in nature, given the loss of legitimacy of politicians and business owners had an influence on the rise in the number of company recoveries which took place in these years. "On the one hand, it created a climate of disobedience and non-conformity which fed the possibility of disobeying the capitalist decision to abandon production. On the other hand, it created a social sensitivity so that recoveries could spread." (Rebón, 2006:155).
} 
According to data collected by COCETA between 2008 and 2009, there were 40 CCCs registered in Spain. The majority are small companies where, after having suffered closures, Regulatory Actions and insolvency proceedings, the workers manage themselves as cooperatives as a way of generating their own employment. Their increase alongside the rise in unemployment and exclusion figures points to the idea that their defensive character is a collective response by the workers faced with a lack of options, not just confronted by high levels of unemployment which reached almost $26 \%$, but also by the continuous rise of short-term labour according to the latest Labour Force Survey for the first quarter of 2014 (Spanish National Statistics Office, INE).

"You see that there's no work; there isn't any and you don't see any quick fix, so you don't have any options. Either you try to do it yourself or what do you do, take unemployment until it finishes?" (CCC worker)

\section{Reasons To Begin The Process Of Self-Management}

At a time when it was not possible to find alternative employment and state benefits were insufficient to support their families, the loss of employment meant, in short, to see oneself become socially excluded. For the Chilavert workers, a situation had solidified where the urgency of avoiding social exclusion was made unprecedentedly clear. The attempts at deceit on the part of the employers and the late or non-payment of salaries after many years - in some cases, over twenty years - are some of the principal reasons that the workers had to begin the process of recovery. As they show, the need to survive determined the resistance to their loss of employment in the face of a lack of other options (Díaz, 2014).

"No, at that time there was no work; these days you're too old to work but too young to retire. You're at basically a critical age." (CRW worker)

In the case of CCCs, although the workers could not rely on any guarantee of security and did not know if they would be able to achieve their objective, they were convinced that their knowledge was their principal resource in the face of a lack of response from political and employer representatives. After having been laid off, they found themselves facing a situation of economic crisis which made it impossible for them to find work that would allow them to meet their basic needs. Uncertainty and labour instability, together with a perception of highly precarious work, were the main reasons for the workers to see cooperative self-management as an alternative source of work.

"When we started, we were convinced that it was possible; you'll see, but for the moment we're going to try it because working is what we know how to do; it's the same as we did before and we can rely on it." (CCC worker)

\section{Why A Cooperative}

The adoption of a cooperative model is a characteristic feature of the majority of CRWs in Argentina. In these cases, it is important to point out the nuances of meaning which they have in the recovery process. As Ruggeri explains, in over $90 \%$ of cases, CRWs have adopted the form of a cooperative due to the legal advantages that such models have recourse to. They can also appeal to expropriation laws and continue to legally make use of company goods, recognised as goods for the use of the public. The protagonists of the action identify themselves as workers, not as cooperativists (Ruggeri, 2009).

As the Chilavert workers explain, adopting horizontal relations and practising "permanent assembly" are a result of the same character of collective struggle undertaken in defence of their work. The difficulty of the circumstances in which they found themselves after having decided to begin the recovery process came from collective decisions. In addition, everything pertinent to the company is dealt with by all workers, since all are considered equal with contributions to make.

"Yes, the cooperative was because that way we could appeal to the law to request expropriation; we had to be a cooperative and so we did it that way." (CRW worker)

In the case of CCC workers, adopting a cooperative organizational model was motivated by its implied features of horizontality and democratization. With the generation and maintaining of work as its objective, the 
beginning of the conversion process, as a collective decision, contained the concept, also collective, of the decisionmaking process. Principal characteristics of cooperatives are identified by the workers as elements of resistance which they consider to be more effective than the principles of hierarchy and individualism of the private company as a means to prevent unemployment.

"In our case, we were clear; we decided to be a cooperative because it was what best suited what we wanted to do. We wanted to act as partners, all equal; we all contribute what we know; we all decide how we go about doing things and how we resolve things." (CCC worker)

\section{Weaknesses}

The most significant problems identified by the Chilavert workers relate to the lack of economic resources which would mean that certain machinery could be renewed. They also pointed out the need to account for more personnel, and the principal difficulty with this is to find workers who do not exclusively value their wage earnings and, instead, are committed to self-management.

"It would be good for us to change some machines, which are old now, but we can't for now. Also, well, it's not easy to find workers who want to become partners; most want to earn more money." (CRW worker)

For the CCC workers, the main weakness is the lack of revenue due to the fall in consumption by Spanish families in the current framework of the crisis. This means that salaries must be adjusted to match the situation. They also mention the excessive bureaucratic steps required, which are costly in both time and money.

"It's just that now people are consuming much less because, of course, they don't have jobs and people don't have money, so now it's difficult for us to make sale.s" (CCC worker)

\section{Strengths}

The main strength indicated by the Chilavert workers is that of having become a group of teammates who have been united by very difficult circumstances. They feel that the will to keep working and trying to resolve daily difficulties is the main resource they rely on. To this they add union, companionship and commitment as fundamental elements in the recovery, as well as the introduction of values and practices of equality and horizontality which have been brought about as part of their self-management.

"For us, the most important thing is our wanting to continue; we've been going eight years, so we can say that so far it's kept us going, as well as the satisfaction that it's us who have done it." (CRW worker)

In the case of the CCC workers, the elements they indicate as principal strengths revolve around the articulation of a collective response which, for now, has allowed them to overcome the loss of employment. The sharing of a common objective, which includes the launch of a project they gave form to and which they are now taking forward with their own resources and criteria, is a constant reinforcement to resist in the face of daily difficulties to be resolved.

"The best thing we have is our conviction, the enthusiasm we have because we feel like we're together and for now we've set it going and that gives you a lot of encouragement." (CCC worker)

\section{Changes To The Perception Of The Work}

The change entailed by collective self-management alludes discursively to two main issues. The individual responsibility of each worker, resulting from the recovery process and its associated appropriation of work, has brought, as a consequence, the learning and discovery of new skills and knowledge.

"For me the most important part of the experience, more than the positive and negative things it can bring, the most important thing is everything that we learn and the skills we discovered about ourselves, which probably wouldn't have come about in another situation." (CRW worker) 
For the CCC workers, their way of perceiving their work has changed fundamentally, not so much in the activities carried out as in the signification that it takes on in self-management. Despite the loss of the security provided by salaries in the previous contractual situation as hired workers, the work now has a very different and positive feel, thanks to the increased involvement and responsibility. In addition, this positive feeling is due to putting into practice all workers' skills and knowledge as a shared resource which feeds back into itself.

"Of course, now it's something else; now you work for yourself, so to speak, and you rely on what you have and it's you who has to be here and who has to find a solution; the responsibility is yours." (CCC worker)

\section{Changes To The Signification Of The Company}

The cooperative model is a way to put into practice a conception of the company and of work which transcends an exclusively productive focus since it demonstrates a compatibility between the conception of company and of work with practising solidarity in the surrounding social context; i.e., the most nearby neighbourhood. The introduction of measures of democratization and solidarity represent, for the workers, a way to develop a management model distinct from the dominant model in the current era of flexible capitalism, where workers suffer the consequences of policies shaped by private and economic interests. The shared vision around the importance of these practices shows the political significance of recovery processes as self-management projects.

"There are lots of differences. We get a lot of satisfaction from allocating spaces for all kinds of activities in the neighbourhood. Even though some CRWs don't do it, for us it was important to give back in some way the support that we received when we needed it." (CRW worker)

For the CCC workers, their view of cooperatives is different under self-management, fundamentally, because compared to the previous situation they worked in, the work itself now takes priority over capital. This change is due to the very objective noted at the start of the conversion process - the important thing is to maintain jobs. There are also other changes, such as the revaluation of human resources, creativity, and setting up initiatives, as a result of their involvement and responsibility in the self-managed workplace.

"For us the important thing is to continue working and that's what we're trying to do. We have activities and projects we're designing for launch and before that, it would have been unthinkable." (CCC worker)

\section{CONCLUSIONS}

In the subjective view of workers in Argentina and Spain, the self-management processes of recovery and conversion, which they have undertaken, are collective responses which share a defensive character in the face of unemployment. The crisis in which both processes appear is perceived as a situation with no options for finding another job to earn a living. The worsening of unemployment and social exclusion as principal problems means that the workers try to maintain their sources of work, taking charge of the management of the company as a feasible alternative.

In both cases, the undertaking of the process is accompanied by the establishment of horizontal relations and collective decision-making, although in the Argentine case, the adoption of a cooperative model is related to the legal advantages granted to cooperatives under the Laws of Temporary and Permanent Expropriation.

In spite of the economic difficulties, the workers can share a common objective which they articulate as a group and which constitutes one of the main strengths and resources in maintaining the self-management model. This model also entails important changes in how work is perceived, as well as to the perception of the company itself, thanks to the workers' greater level of involvement and responsibility whereby the work and human resources achieve a priority over that of capital. 


\section{AUTHOR INFORMATION}

Susana B. Díaz Ruiz holds a PhD in Sociology from the Universidad Complutense de Madrid, Spain. She is currently a Lecturer in Sociology in Labour Relations and Human Resource Development. She is based at the Department of Philosophy (Area of Sociology) in the Faculty of Social Science at Cuenca University of Castilla La Mancha, Spain. Her principal research interests are labour, collective identity, qualitative analysis and participatory methodologies. Email: susana.diaz@uclm.es.

\section{REFERENCES}

1. $\quad$ Alonso, L. E. (2000). Trabajo y posmodernidad: el empleo débil. Madrid: Fundamentos.

2. Castells, M. (2005). La era de la información: economía, sociedad y cultura., Vol. I La sociedad red. Madrid: Alianza Editorial.

3. Castillo, J. J. (2003). En la jungla de lo social: reflexiones y oficio de sociólogo. Madrid: Miño y Dávila.

4. Carnoy, M. (2001). Etrabajo flexible en la era de la información. Madrid: Alianza Editorial.

5. Cadena Ser. (2014). "Las empresas convertidas en cooperativas salvan 700 puestos de trabajo en 2013" at Cadena Ser: http://www.cadenaser.com/economia/articulo/empresas-convertidas-cooperativas-salvan-700-puestostrabajo-2013/csrcsrpor/20140421csrcsreco_1/Tes (accessed 2nd April, 2014).

6. CECOP - CICOPA. (2013). "Business Transfers to Employees under the Form of a Cooperative in Europe Opportunities and Challenges":

http://www.cecop.coop/IMG/pdf/bussiness transfers to employees under the form of a cooperative in _europe_cecop-2.pdf (accessed 2nd February, 2014).

7. Coraggio, J. L. (2004). La gente o el capital: desarrollo local y economía del trabajo. Buenos Aires, Espacio.

8. Díaz, Susana B. (2014). "Significaciones y prioridades en la autogestión de las ERT argentinas. El caso de Chilavert ocho años después de su recuperación", Cuadernos de Relaciones Laborales, Vol. 32, n. 1, (forthcoming).

9. Fajn, G. (compilation). (2003). Fábricas y Empresas Recuperadas. Protesta social, autogestión y rupturas en la subjetividad. Buenos Aires: Ediciones del Instituto Movilizador de Fondos Cooperativos.

10. Felber, C. (2012). La economía del bien común. Deusto: S.A Ediciones.

11. Instituto Nacional Estadística y Censos Argentina (INDEC). (2002). Evolución de la indigencia, la pobreza y la desocupación en el GBA.

12. Magnani, E. (2003). El cambio silencioso. Empresas y fábricas recuperadas por los trabajadores en la Argentina. Buenos Aires: Prometeo.

13. Perelman, L. (2002). "Patrones de participación en el mercado aboral de los trabajadores del Gran Buenos Aires", Serie Documentos de trabajo Núm. 141, Equipo Técnico Mutidisciplinario, Santiago de Chile: OIT.

14. Prieto, C. (2002). "La degradación del empleo o la normal social del empleo flexibilizado", Sistema: Revista de ciencias sociales. Núm. 168-169, 89-106.

15. Programa Facultad Abierta (PFA). (2004). Informe del Segundo Relevamiento de ERT. Facultad de Filosofía y Letras UBA at www.recuperadasdoc.com.ar.

16. Programa Facultad Abierta (PFA). (2010). Informe del Tercer Relevamiento de ERT. Facultad de Filosofía y Letras UBA at www.recuperadasdoc.com.ar.

17. Programa Facultad Abierta (PFA). (2014). Informe del Tercer Relevamiento de ERT. Facultad de Filosofía y Letras UBA at www.recuperadasdoc.com.ar.

18. Razeto, L. (2006). Lecciones de Economía Solidaria. Realidad, Teoría y Proyecto. Santiago, Ediciones UVIRTUAL.NET, Santiago 2006.

19. Rebón, J. (2004). Desobedeciendo al desempleo. La experiencia de las empresas recuperadas. Buenos Aires: Ed. La Rosa Blindada/PICASO.

20. Rebón, J. (2006). "Las empresas recuperadas por sus trabajadores en Argentina”, Cuadernos de relaciones laborales. Vol. 24, Núm. 2, 149-172.

21. Ruggeri, A. (compilation). (2009). Las empresas recuperadas. Autogestión obrera en Argentina y América Latina. Buenos Aires: Ed. De la Facultad de Filosofía y Letras.

22. Ruggeri, A., Martínez, C. \& Trinchero, H. (2005) Las empresas recuperadas en la Argentina. Informe del segundo relevamiento entre empresas recuperadas por sus trabajadores. Buenos Aires: Facultad de 
Filosofía y Letras. Universidad de Buenos Aires

23. Sennett, R. (2000). La corrosión del carácter: las consecuencias personales del trabajo en el nuevo capitalismo. Barcelona: Anagrama.

24. Vilnitzky, M. (2014) "Cuando los trabajadores se quedan con la empresa”, Alternativas Económicas n. 11, 56-57. 